Ks. Piotr SZCZUR*

\title{
ROLA POSTRZEGANIA DUCHOWEGO W NAUCZANIU KATECHETYCZNYM JANA CHRYZOSTOMA
}

\author{
Z czasów kapłańskiej działalności Jana Chryzostoma w Antiochii (lata \\ 386-397) ${ }^{1}$ zachowało się dwanaście katechez chrzcielnych ${ }^{2}$. W czasie trzy- \\ dziestodniowego okresu ${ }^{3}$ przeznaczonego na nauki poprzedzające chrzest ${ }^{4}$,
}

\footnotetext{
${ }^{*}$ Ks. dr hab. Piotr Szczur, prof. KUL - kierownik Katedry Historii Kościoła w Starożytności i Średniowieczu w Instytucie Historii Kościoła i Patrologii na Wydziale Teologii Katolickiego Uniwersytetu Lubelskiego Jana Pawła II; e-mail: p.szczczur@kul.pl.

${ }^{1}$ Od końca 380 lub początku roku 381, Chryzostom był diakonem. Święceń udzielił mu biskup Melecjusz (por. Palladius, Dialogus de vita Iohannis Chrysostomi 5, ed. A.M. Malingrey - P. Leclercq, SCh 341, Paris 1988, 110; J.N.D. Kelly, Złote usta. Jan Chryzostom - asceta, kaznodzieja, biskup, tłum. K. Krakowczyk, Bydgoszcz 2001, 49; C. Tiersch, Johannes Chrysostomus in Konstantinopel (398-404). Weltsicht und Wirken eines Bischofs in der Hauptstadt des Oströmischen Reiches, [Studien und Texte zu Antike und Christentum 6], Tübingen 2002, 60). Na prezbitera został wyświęcony na początku 386 roku, lecz nie wcześniej niż 15 lutego. Odnośnie daty święceń zob. Ch. Baur, Der heilige Johannes Chrysostomus und seine Zeit, t. 1: Antiochien, München 1929, 180; L. Brottier, Introduction, w: Jean Chrysostome, Sermons sur La Genèse, SCh 433, Paris 1998, 11; Kelly, Złote usta, s. 49, 65; Tiersch, Johannes Chrysostomus in Konstantinopel (398-404), s. 60-61.

${ }^{2}$ Znane są trzy kolekcje katechez chrzcielnych Jana Chryzostoma: 1. Dłuższy zbiór - zawierający osiem katechez - znany jest jako seria Stavronikity, ed. A. Wenger, SCh 50bis, Paris 1970, 107-260, thum. W. Kania w: Św. Jan Chryzostom, Katechezy chrzcielne (homilie katechetyczne do tych, którzy maja być oświeceni oraz do neofitów, wstęp i oprac. M. Starowieyski, U źródeł katechumenatu 1, Lublin 1993, 23-118; 2. Krótszy zbiór - zawierający trzy katechezy - znany jest jako seria Papadopoulosa - Kerameusa, ed. A. Piédagnel, SCh 366, Paris 1990, 110-242, thum. W. Kania w: Św. Jan Chryzostom, Katechezy chrzcielne (homilie katechetyczne do tych, którzy maja otrzymać chrzest [zostać oświeceni] oraz do neofitów 9-12, oprac. M. Starowieyski, U źródeł katechumenatu 2, Lublin 1994, 9-50; 3. Zbiór z edycji B. de Montfaucon'a zawierający dwie katechezy, PG 49, 223-240, thum. katechezy drugiej W. Kania w: Św. Jan Chryzostom, Katechezy chrzcielne (homilie katechetyczne do tych, którzy mają otrzymać chrzest [zostać oświeceni] oraz do neofitów 9-12), oprac. M. Starowieyski, U źródeł katechumenatu 2, Lublin 1994, 51-68; należy jednak zaznaczyć, że pierwsza katecheza z edycji Montfaucon'a odpowiada pierwszej katechezie ze zbioru Papadopoulosa - Kerameusa; tak więc w sumie jest dwanaście różnych katechez chrzcielnych. Kryteria wewnętrzne pozwalają na zidentyfikowanie trzech pierwszych katechez z kolekcji Stavronikity (1-3) jako przedchrzcielnych, zaś pięciu kolejnych (4-8) jako pochrzcielnych (mistagogicznych).

${ }^{3} \mathrm{Na}$ trzydzieści dni przed Wigilią Paschalną odbywało się zapisywanie kandydatów do chrztu.

${ }^{4}$ Por. Joannes Chrysostomus, Ad illuminandos, catechesis 1, 2, SCh 366, 114, tłum. Kania, II, s. 10: „Ja nie mówię: «Jeszcze trzy dni, a otrzymacie od króla urząd podczaszego» (por. Rdz 40, 13),
} 
Chryzostom wygłosił kilka katechez chrzcielnych ${ }^{5}$. W katechezach tych starał się wyjaśnić znaczenie obrzędów, w których katechumeni uczestniczyli: „,...] nauczcie się ode mnie - o ile to tylko możliwe - znaczenia różnych obrzędów, byście stąd odeszli z pełną ich znajomością" oraz zachęcić ich do patrzenia na nie oczami wiary ${ }^{7}$ :

„Wszyscy, którzy dostąpiliście wpisania was do niebieskiej księgi, wznieście wielką wiarę i mocne postanowienie. Wiary bowiem potrzeba w rzeczach, które się tu dzieją, i oczu duszy, by nie tylko o tym myśleć, co się widzi, ale by i to sobie uprzytomnić, czego się nie widzi. A tę właściwość mają oczy duszy: jak oczy ciała widzą to, co podpada pod zmysły, to te nie widzą rzeczy widzialnych, lecz niewidzialne, jak gdyby one leżały przed nami! $\mathrm{Na}$ tym bowiem polega wiara, iż choć czegoś nie widzimy, jednak to uznajemy, jakbyśmy je widzieli. «Wiara» - mówi Pismo Święte - «jest podstawą tego, czego oczekujemy, jest dowodem na to, czego nie widzimy» (Hbr 11, 1). Co oznaczają te słowa i czemu odwracam waszą uwagę od rzeczy widzialnych, a zwracam ją na rzeczy duchowe? Abyś, gdy zobaczysz wodę i wyciągniętą nad twą głową rękę kapłana, nie uważał jej za zwykłą wodę i że tylko ręka biskupa dotyka twej głowy. Bo nie człowiek tego dokonuje, co się tu dzieje, ale łaska Ducha. On uświęca naturę wody, ona wraz z ręką kapłana dotyka twej głowy. Czyż więc niesłusznie powiedziałem, iż potrzeba nam oczu wiary, aby wierzyć w rzeczy niewidzialne, by nie szukać tego tylko, co widzialne?"».

Uwieńczeniem przygotowań katechumenów był ich chrzest i pełny udział w Eucharystii, która dla Chryzostoma stanowiła uobecnienie wydarzeń zbawczych związanych z życiem i działalnością Jezusa Chrystusa oraz kosmicznych konsekwencji tych wydarzeń. Przykładowo, w homilii wygłoszonej podczas święta męczennika Filogoniusza ${ }^{9}$, Chryzostom porównał

lecz mówię: «Jeszcze trzydzieści dni, a nie faraon, lecz Król niebieski przyjmie was do niebieskiej ojczyzny, do wolnego Jeruzalem, do niebieskiego miasta»"; Harkin, John Chrysostom, s. 290.

${ }^{5}$ Zachowały się katechezy wielkopostne z roku 388 i 390.

${ }^{6}$ Joannes Chrysostomus, Catecheses ad illuminandos 2, 12, SCh 50bis, 139, thum. Kania, I, s. 45.

${ }^{7} \mathrm{Na}$ temat roli „duchowego wzroku” w teologii patrystycznej por. M. Canévet, Sens spirituel, DSp XIV 599-617; B. Fraigneau-Julien, Les sens spirituels et la vision de Dieu selon Syméon le Nouveau Théologien, Paris 1985, passim; P. Szczur, Rola „,zmysłów wiary” w zrozumieniu sakramentów inicjacji chrześcijańskiej wedlug Cyryla Jerozolimskiego, VoxP 34 (2014) t. 61, 297-308.

${ }^{8}$ Tamże 2, 9-10, SCh 50bis, 138-139, thum. Kania, I, s. 44.

${ }^{9}$ Uczeni na ogół są zgodni, że homilia ta została wygłoszona w 386 r. Niektórzy wskazują nawet konkretną datę - 20 XII 386: Louis Sebastian Lenain de Tillemont (Mémoires pour servir à l'histoire ecclésiastique des six premiers siècles, t. 11, Paris 1706, 57), Bernard de Montfaucon (Sancti Patris Nostri Joannis Chrysostomi Archiepiscopi Constantinopolitani Opera omnia quae exstant, vel quae eius nomine circumferentur, Ad MSS. Codices Gallicanos, Vaticanos, Anglicanos, Germanicosque; necnon ad Savilianam et Frontonianam editiones castigata, innumeris aucta; nova interpretatione ubi opus erat, praefationibus, monitis, notis, variis lectionibus illustrata; nova Sancti Doctoris vita, appendicibus, onomastico et copiosissimis indicibus locupletata, t. 1, Parisiis 1718, 492), Joannes Stilting (De S. Joanne Chrysostomo, Episcopo Constantinopolitano et Eccle- 
Eucharystię złożoną na ołtarzu do ciała nowo narodzonego Chrystusa złożonego w stajence: „Tu jest położone ciało Pana, nie w powijakach jak kiedyś, ale całkowicie odziane w Ducha Świętego"10. Podkreślał, że podobnie jak niegdyś Mędrcy ze Wschodu przyszli do nowo narodzonego dziecięcia, tak teraz ochrzczeni moga przyjść do Chrystusa i ofiarować Mu dary cnót. Typologia mędrców pojawiająca się w wypowiedzi Chryzostoma była znacząca i wymowna, ponieważ nadawała wymiar historyczny odczuciom (zwłaszcza zmysłowym) i postawom tych, którzy zbliżali się do Chrystusa w Eucharystii.

W Katechezach Chryzostoma można dostrzec nieustanną jego troskę o symbolikę gestów i postaw nowo ochrzczonych. Dla niego,,widok gołych stóp i wzniesionych ku niebu rąk” stanowił wyraźne przypomnienie ,zniewolenia ciała" przez szatana ${ }^{11}$. Chryzostom przypominał nowym chrześcijanom:

„Zwróć też uwagę na formę niewoli. Prowadzący was kapłani każą wam wpierw zgiąć kolana, podnieść ręce ku niebu i tak się modlić. Przez tę postawę winniście sobie uprzytomnić, z czego się zwalniacie i z kim macie się złączyć"12.

Wierni mieli rozumieć i zachować w pamięci swoje postawy i gesty, gdyż miały one wymiar duchowy. Kiedy katechumeni z gołymi stopami, klęcząc wyciągali swe ręce do góry i wypowiadali słowa: „odrzekam się ciebie, szatanie, odrzekam się twej pychy, twej chwały, twych spraw!"13, aniołowie przyjmowali tę deklarację i zanosili ją przed tron Boga. Zwracając uwagę

siae Doctore, prope Comana in Ponto, commentarius historicus, w: Acta Sanctorum Septembris, t. 4: Quo dies duodecimus, decimus tertius et decimus quartus continentur, Antverpiae 1753, 452), Gerhard Rauschen (Jahrbücher der christlichen Kirche unter dem Kaiser Theodosius dem Grossen. Versuch einer Erneuerung der Annales Ecclesiastici des Baronius für die Jahre 378-395, Freiburg im Breisgau 1897, 503), Eduard Schwartz (Christliche und jüdische Ostertafeln, Abhandlungen der Königlichen Gesellschaft der Wissenschaften zu Göttingen. Philologisch-historische Klasse NF 8, Nr 6, Berlin 1905, 176), Max von Bonsdorff (Zur Predigttätigkeit des Johannes Chrysostomus, biographisch-chronologische Studien über seine Homilienserien zu neutestamentlichen Büchern, Helsingfors 1922, 3). Johannes Quasten (St. John Chrysostom, w: Patrology, t. 3: The Golden Age of Greek Patristic Literature From the Council of Nicaea to the Council of Chalcedon, Utrecht Antwerp 1960, 451) nie wskazuje dokładnej daty, lecz twierdzi, że homilia ta została wygłoszona w Konstantynopolu (być może w roku 397 - co jednak wydaje się mało prawdopodobne). Por. W. Mayer, The Homilies of St. John Chrysostom: Provenance. Reshaping the Foundations, OCA 273, Rome 2005, 69, 106, 131, 145, 150, 200, 218 i 259.

${ }^{10}$ Joannes Chrysostomus, De beato Philogonio 4, PG 48, 753, thum. własne.

${ }^{11}$ Por. Joannes Chrysostomus, Catecheses ad illuminandos 2, 14, SCh 50bis, 141. Szerzej na temat związku pomiędzy chrztem a niewolą zob. I.A.H. Combas, The Metaphor of Slavery in the Writings of the Early Church: From the New Testament to the Beginning of the Fifth Century, Sheffield 1998, 110-120 i 157-161.

${ }^{12}$ Joannes Chrysostomus, Catecheses ad illuminandos 2, 18, SCh 50bis, 143-144, thum. Kania, I, s. 47. Por. tenże, Catechesis ultima ad baptizandos 4, SCh 366, 230.

${ }^{13}$ Joannes Chrysostomus, Catecheses ad illuminandos 2, 20, SCh 50bis, 145, thum. Kania, I, s. 48. 
na detale postawy: nagie stopy, ugięte kolana i dłonie wzniesione ku niebu, Chryzostom starał się pobudzić duchowe zmysły, które nie tylko pozwolą wyobrazić sobie, lecz także „zobaczyć” to, co jest niewidoczne dla cielesnych oczu. Poza gestami i postawami, które miały przede wszystkim znaczenie symboliczne, chrzest powodował też zmiany w wyglądzie twarzy i ciała, które dla duchowych zmysłów również były widoczne.

Złotousty kaznodzieja thumaczył, że neofici, wkraczając w nowy etap życia, rozpoczynali udział w pewnego rodzaju ,zawodach” $i$ od tej pory byli obserwowani przez ludzi i aniołów:

„Od dziś otwarte jest przed wami pole walki. Patrzą na was nie tylko ludzie, lecz i aniołowie"14.

Walkę tę toczyli z odwiecznym wrogiem człowieka - z szatanem. Jednak Chryzostom podkreśla, że chrześcijanin znajduje się w lepszym położeniu niż szatan, gdyż po jego stronie jest Chrystus. Antiocheńczyk - nawiązując do obrzędów chrzcielnych - podkreśla też, że sam Chrystus namaścił neofitę olejkiem radości przygotowując go do walki z szatanem ${ }^{15}$ oraz dał odpowiednią broń ${ }^{16}$. Co więcej, Chryzostom akcentuje, że Chrystus przygotował też dla wierzącego specjalny pokarm, aby w tej walce nie zabrakło mu sił, a Krew Chrystusa zabarwiała usta chrześcijanina po to, by odstraszyć szatana:

„Czy tylko broń dał Ci Bóg? Nie, przygotował też pokarm mocniejszy od wszelkiej broni, byś nie ustał w walce, byś zwyciężył złego. Gdy tylko ujrzy, że idziesz z uczty Pańskiej, jak ktoś na widok ziejącego ogniem lwa zbiegnie szybciej od wiatru. Gdy mu pokażesz drogą krwią zabarwiony język, nie zdoła się zatrzymać, gdy mu dasz ujrzeć zaczerwienione usta, jak nędzne zwierzę zaraz pierzchnie"17.

Widzimy zatem, że $w$ różnych obrzędach związanych $\mathrm{z}$ inicjacją chrześcijańską Chryzostom dostrzegał inne rzeczywistości, które miały m.in.

${ }^{14}$ Joannes Chrysostomus, Catecheses ad illuminados 3, 8, SCh 50bis, 155, thum. Kania, I, s. 55.

${ }^{15}$ Por. tamże 3, 9, SCh 50bis, 155-156, thum. Kania, I, s. 55: „W naszej walce z szatanem stoi Chrystus - nie w środku [jak sędzia - P.Sz.], lecz po naszej stronie. Z czego to wnosimy? Z tego, że nas do walki namaścił, a szatana związał. Nas namaścił olejkiem radości, jego zaś związał więzami nie do rozerwania, by go unieszkodliwić w napadach. Mnie w razie upadku podaje rękę, podnosi i stawia na nogi".

${ }^{16}$ Por. tamże 3, 11, SCh 50bis, 157-158, tłum. Kania, I, s. 56: „Da nam [Chrystus] broń jaśniejszą od złota, mocniejszą od stali, gorętszą od ognia, lżejszą od powietrza. Ta broń nie obciąża nóg, lecz je uskrzydla i podnosi w górę. Gdybyś nawet pragnął wylecieć pod niebo, broń ta nie przeszkadza. Natura jej nowa, bo i rodzaj walki nowy. Człowiekiem będąc, muszę uderzyć na szatanów, obleczony w ciało muszę stoczyć walkę z bezcielesnymi potęgami. Dlatego dał mi Bóg pancerz nie z żelaza, lecz ze sprawiedliwości, dzierżę w ręku miecz ostry - słowo Ducha. Szatan wypuszcza na mnie strzały, ja trzymam miecz. On jest łucznikiem, ja hoplitą. Łucznik nie śmie przyjść bliżej wypuszcza strzały z daleka".

${ }^{17}$ Tamże 3, 12, SCh 50bis, 158, thum. Kania, I, s. 56. 
odstraszyć szatana. Złotousty kaznodzieja tłumaczył, że przy namaszczeniu czoła podczas chrztu, szatan „musiał odwracać wzrok. Nie ma bowiem odwagi nań spoglądać, z powodu blasku bijącego z tego namaszczenia, oślepiającego jego wzrok" ${ }^{18}$. Nietrudno więc zauważyć, że w katechezach chrzcielnych, Chryzostom wpajał katechumenom liczne wyobrażenia cielesne, dzięki którym mieli sobie wyobrażać siebie samych takimi, jakimi wydawali się innym chrześcijanom, aniołom i szatanowi. Bagaż tych wyobrażeń towarzyszył neoficie przez całą liturgię, aż do momentu podejścia do samego ołtarza, z którego miał otrzymać Eucharystię.

Aby owe obrazy fizyczne nabrały mocniejszego wyrazu Chryzostom uzupełniał je osadzając $w$ przestrzeniach teologii i egzegezy biblijnej. Przykładowo, eucharystyczne wino porównywał do krwi, którą Izraelici naznaczyli próg i odrzwia swych domów (por. Pwt 12, 22). Widok krwi odstraszał anioła śmierci i zmuszał go do oszczędzenia wszystkich, którzy pozostawali za drzwiami oznaczonymi krwią. Antiocheńczyk podkreśla, że wino eucharystyczne jawiło się szatanowi jako „krew prawdy na wargach wiernych”:

„Dzięki krwi na drzwiach nie śmiał wejść do domu anioł śmierci. Gdy teraz szatan widzi nie krew figury na drzwiach, lecz krew prawdy na wargach wiernych znaczącą drzwi świątyni Chrystusowej, czyż nie ustąpi o wiele prędzej? Skoro ustąpił anioł, i to na widok figury, ileż prędzej ucieknie szatan na widok rzeczywistości!"’19.

W opisie tym wyraźnie można dostrzec aluzję do Paschy Izraelitów (por. $\mathrm{Wj} 12$ ), nie tylko ze względu na to, że krew baranka paschalnego chroniąca przed aniołem śmierci została ukazana jako figura wina eucharystycznego chroniącego przed atakami złego ducha, lecz także na porównanie ciała chrześcijanina przyjmującego Eucharystię do budowli ,świątyni Chrystusowej”, a jego ust do elementu architektonicznego tej świątyni - do drzwi.

To porównanie katechumena do budowli pojawia się też we wcześniejszej katechezie chrzcielnej dotyczącej egzorcyzmów. W katechezie tej Chryzostom zachęcał katechumenów, aby wyobrazili sobie siebie samych jako domy, które stały się godne, aby w swych progach przyjąć Króla niebieskiego. Do tego finału katechumenów prowadzili egzorcyści, którzy przygotowując mieszkanie dla królewskiego gościa oczyszczali serca od wpływów szatana ${ }^{20}$. Widzimy zatem jak Chryzostom skłaniał wiernych do tworzenia wizji, w której mieli się utożsamić z „budowlą Chrystusową” i poszczególnymi jej elementami.

${ }^{18}$ Tamże 2, 23, SCh 50bis, 146-147, thum. Kania, I, s. 49.

${ }^{19}$ Tamże 3, 15, SCh 50bis, 159, thum. Kania, I, s. 57.

${ }^{20}$ Por. tamże 2, 12, SCh 50bis, 140, tłum. Kania, I, s. 45: „Winniście zatem wiedzieć, dlaczego po każdej nauce odsyłamy was do tych, których głos was egzorcyzmuje. Nie jest bez znaczenia ten obrzęd. [Skoro] macie przyjąć jako gościa Króla niebieskiego, przeto ci, którym zlecono przygotowanie Mu mieszkania, tymi straszliwymi słowami oczyszczają wasze serca, udaremniając wszelkie zasadzki złego ducha”. 
Antiocheńczyk twórczo wykorzystał zastosowanie obrazowania architektonicznego dla zaszczepienia personifikacyjnej mnemotechniki. Często sytuował ciało katechumena w przestrzeni, np. kiedy opisywał

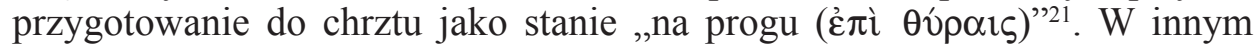
miejscu - kiedy zbliżał się moment chrztu, przypominał katechumenom, że znajdują się „,W przedsionkach królewskich i mają zbliżyć się do tronu, na którym siedzi rozdzielający dary Król"22. Zaś gdy już zostali ochrzczeni i wyzwoleni z niewoli złego ducha, neofici ,idą zaraz do pełnego grozy stołu, źródła tysięcznych dóbr, gdzie spożywają Ciało i Krew Pańską i stają się mieszkaniem Ducha"23. Wierni wzywani byli nie tylko do wyobrażenia sobie danej przestrzeni, ale poruszania się w jej ramach i zbliżenia do elementów jej wyposażenia.

Wydaje się, że w tych obrazach nie ma nic nowego: świątynie, drzwi i budowle (mieszkania) zawsze były (i wciąż pozostają) typowymi metaforami życia chrześcijanina, a szczególnie jego ciała ${ }^{24}$. A jednak, za tymi metaforami kryje się coś więcej niż tylko proste odwoływanie się do tradycyjnych symboli. Chryzostom zachęcał neofitów do dostrzeżenia tej duchowej przestrzeni oraz do stania się nią. Dlatego często ubogacał swoje wezwania wymowną symboliką. Dzięki tym poczynaniom złotousty kaznodzieja zjednoczył duchowe przestrzenie z doświadczeniem zmysłowym, a więc generował obrazy przestrzeni zabudowując je abstrakcyjnymi doświadczeniami zmysłowymi.

Ta zdolność doświadczenia zmysłowego do tworzenia zabudowanej przestrzeni duchowej, w sposób szczególny widoczna jest w katechezach głoszonych w kulminacyjnym okresie poprzedzającym obchody Wielkanocy. Przykładowo, przestrzeń raju jako „mieszkania” pierwszego człowieka oraz brama („wejście") do niego, były najbardziej uwydatnione w opisie wygnania Adama $\mathrm{z}$ raju ${ }^{25}$. Dla Chryzostoma istotne było nie to, że Bóg wypędził Adama $\mathrm{z}$ raju, lecz to, gdzie go umieścił. Złotousty kaznodzieja twierdził, że nawet po wygnaniu Adam pozostawał dość blisko raju, aby mógł wciąż wpatrywać się w zamknięte bramy Edenu i ubolewać nad swym losem. Chryzostom tak wyjaśniał zastosowanie przez Boga kary polegającej na pozostawieniu Adama w pobliżu bramy do raju:

„[Bóg] zamknął przed nim [tj. Adamem] wejście, aby w każdej chwili mógł rozmyślać, jakich przez swą lekkomyślność pozbawił się darów, bez ustanku korzystać z upomnienia i na przyszłość więcej się starać o zachowanie

${ }^{21}$ Tamże 2, 12, SCh 50bis, 139, thum. Kania, I, s. 45.

${ }^{22}$ Tamże 2, 29, SCh 50bis, 149, thum. Kania, I, s. 51.

${ }^{23}$ Tamże 2, 27, SCh 50bis, 149, thum. Kania, I, s. 50.

${ }^{24}$ Por. 1Kor 3, 16-17. Na temat roli architektury w starożytnych systemach mnemotechnicznych zob. M. Carruthers, The Craft of Thought: Meditation, Rhetoric, and the Making of Images, 400-1200, Cambridge 1998, 16-22.

${ }^{25}$ Por. Joannes Chrysostomus, Catecheses ad illuminados 2, 3-7, SCh 50bis, 134-137, thum. Kania, I, s. 42-43. 
przykazań. Posiadając bowiem dobra, nie umiemy z nich korzystać, a gdy je dopiero stracimy, rozumiemy je lepiej, stąd bardziej cierpimy"26.

Krótko mówiąc, chociaż Adam został wypędzony z Edenu, to jednak utracony raj nadal pozostawał w polu jego widzenia, a dzięki temu - jak Chryzostom zapewniał słuchaczy - człowiekowi pozostawała nadzieja, że nawet utrudnione spoglądanie na Eden - z oddali - mogło antycypować ,pełniejszą percepcję" tej rzeczywistości. Warto również zauważyć, że ta ,pełniejsza percepcja” była ograniczona tylko do jednego zmysłu: mianowicie do zmysłu wzroku. Chryzostom nie mówił słuchaczom, że poza bramami raju Adam wdychał zapachy raju, ani że podsłuchiwał jego odgłosy ${ }^{27}$. Pełniejsza percepcja oznaczała tu po prosty ,,pełniejsze widzenie”.

Wzmianka Chryzostoma, pojawiająca się w kontekście obrzędów chrzcielnych, o spoglądaniu Adama w kierunku raju, stanowiła istotne tło dla doświadczenia udziału w Eucharystii. Podobnie jak Adam, chrześcijanin uczestniczący w Eucharystii obserwował obrzędy eucharystyczne z pewnego oddalenia. Ponadto ołtarz - centralny element tychże obrzędów - znajdował się (podobnie jak raj) w widocznej, lecz jednak odgraniczonej przestrzeni. Jak wykazują historycy architektury, pod koniec IV w. w kościołach bizantyjskich znajdowała się przegroda oddzielająca absydę od nawy. Jednak ten templon - sięgający do pasa parawan z otworami na kształt dużych okien, nie uniemożliwiał wiernym obserwowania Eucharystii. Dopiero w późniejszych wiekach otwory templonu zostały wypełnione ikonami, a wejścia zasłonięte kurtynami i stał się on iconostasis, który dobrze jest znany z kościołów bizantyńskich ${ }^{28}$.

Biorąc pod uwagę fakt, że obrzędy eucharystyczne nie były ukrywane przed nowo ochrzczonymi i odbywały się otwarcie, niejako na ich oczach, można zapytać, co zatem znaczy ,pełnia percepcji”? W przypadku katechumenów oczekujących na pierwszą komunię, „pełnia percepcji” mogłaby być interpretowana jako bycie naocznym świadkiem obrzędu eucharystycznego, co było przywilejem, którego do tej pory im odmawiano. Czy możemy być jednak pewni, że rzeczywistym celem ,„pełniejszej percepcji” było ,patrzenie”

${ }^{26}$ Tamże 2, 6, SCh 50bis, 136, tłum. Kania, I, s. 43.

${ }^{27}$ Np. pogląd Chryzostoma (In Genesim ser. 1, 2, ed. L. Brottier, SCh 433, Paris 1998, 148, tłum. S. Kaczmarek, ŹMT 45, Kraków 2008, 54), że w raju, przed grzechem pierworodnym i wygnaniem, „Bóg sam komunikował się z ludźmi”. W Hymnach o raju Efrema Syryjskiego (por. Hymnus 1, 5; 4, 7; 5, 6; 9, 17; 11, 1. 9-10. 13. 15) znajdują się sugestywne opisy woni raju; szerzej na ten temat zob. S.A. Harvey, St. Ephrem on the Scent of Salvation, JTS 49(1998) 109-128 (spec. 122-123).

${ }^{28}$ Por. C. Mango, On the History of the Templon and the Martyrion of St. Artemios at Constantinople, „Zograf” 10 (1979) 40. Na temat „widzialności” i „ukrycia” zob. T.F. Mathews, The Early Churches of Constantinople: Architecture and Liturgy, Pennsylvania 1971, 105-180; S. Gerstel, Beholding the Sacred Mysteries: Programs of the Byzantine Sanctuary, Seatle - London 1999, 3767. Na temat ikonostasów zob. T. Ware, The Orthodox Church, Harmondsworth 1964, 267-277; P. Florenski, Ikonostas i inne szkice, Warszawa 1984; H. Paprocki, Ikonostas, EK VII 18-20. 
na obrzędy Eucharystii? Jan Chryzostom przecież dość często nawoływał katechumenów i neofitów w swoich naukach katechetycznych, aby patrzyli

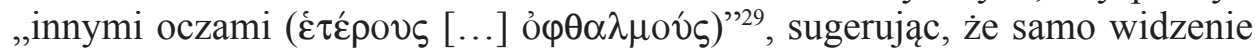
nie jest wystarczające. Ograniczenia takiego wzroku stają się oczywiste, kiedy widzimy, jak Chryzostom traktuje oczy i wzrok.

W katechezach Chryzostom często nawiązywał do pełniejszej lub wzbogaconej percepcji. Narząd, którzy to umożliwiał nazywany był przez niego: „oczy duszy”

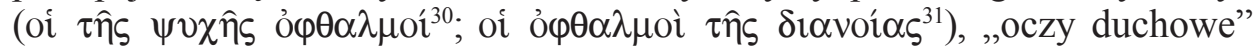

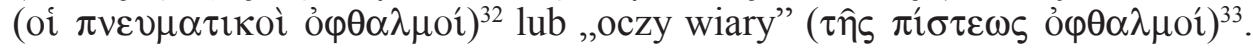
Wszystkie te określenia oznaczały sposób widzenia, który postrzega to, co jest niedostrzegalne dla oczu ciała, czyli fizycznego wzroku. Ponadto, ta forma duchowego widzenia umożliwiała, ,by i to sobie uprzytomnić, czego się nie widzi" ${ }^{34}$. Ilekroć Chryzostom starał się rozróżnić pomiędzy światem widzialnym, który postrzegały oczy ciała, a niematerialnym, duchowym, dostrzegalnym jedynie dla przez duchowe oczy, odwoływał się do tego szczególnego zmysłu. Najbardziej szczegółowe wyjaśnienie tej koncepcji pojawiło się w Chryzostomowym objaśnieniu obrzędu chrztu:

„Dlatego Bóg dał nam dwoje oczu: jedno ciału, drugie duszy. Gdy przystąpisz do tych świętych tajemnic, oczy ciała zobaczą wodę, a oczy wiary patrzeć będą na Ducha. Pierwsze kontemplować będą zanurzone ciało, drugie pogrzebanego starego człowieka (por. Ef 4, 22), pierwsze - obmyte ciało, te - oczyszczoną duszę; pierwsze widzą wynurzające się z wód ciało, drugie spoglądają na nowego człowieka lśniącego i wznoszącego się z tego świętego oczyszczenia. Pierwsze widzą kapłana podnoszącego, potem wkładającego rękę i dotykającego głowy, drugie zaś kontemplują Wielkiego Kapłana rozpościerającego niewidzialnie swą prawą rękę z niebios i dotykającego głowy"35.

W przytoczonej wypowiedzi Jana Chryzostoma retoryka zakłada podwójne widzenie: fizyczne i duchowe. Aby właściwie odczytać znaczenie poszczególnych elementów obrzędu chrztu postrzeganie zmysłowe musi współdziałać z postrzeganiem duchowym. Dzięki tej oscylacji Chryzostom ściśle wiązałze sobąoba sposoby widzenia, nawet jeśli różniły sięw swojej treści.

\footnotetext{
${ }^{29}$ Joannes Chrysostomus, Catecheses ad illuminados 1, 31, SCh 50bis, 124, thum. Kania, I, s. 33.

${ }^{30}$ Tamże 2, 9, SCh 50bis, 138, thum. Kania, I, s. 44; tamże 2, 17, SCh 50bis, 143, thum. Kania, I, s. 47.

${ }^{31}$ Tamże 4, 14, SCh 50bis, 190, tłum. Kania, I, s. 68; tamże 4, 20, SCh 50bis, 193, tłum. Kania, I, s. 70.

${ }^{32}$ Tamże 2, 28, SCh 50bis, 149, thum. Kania, I, s. 50.

${ }^{33}$ Tamże 2, 10, SCh 50bis, 139, tłum. Kania, I, s. 44. Termin ten jest także stosowany w od-

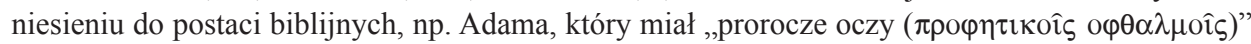
(tamże 1, 13, SCh 50bis, 115, tłum. Kania, I, s. 27) i Dawida, który również miał ,prorocze oczy

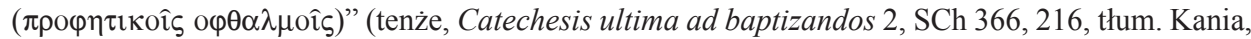
I, s. 41). Szerzej na temat postaci biblijnych patrzących „oczami wiary” zob. G. Frank, The Memory of the Eyes. Pilgrims to Living Saints in Christian Late Antiquity, Berkeley 2000, 102-170.

${ }^{34}$ Joannes Chrysostomus, Catecheses ad illuminados 2, 9, SCh 50bis, 138, tłum. Kania, I, s. 44.

${ }^{35}$ Tenże, Catechesis ultima ad baptizandos 3, SCh 366, 220-222, thum. Kania, I, s. 42.
} 
W tym miejscu warto podkreślić współpracę wzroku cielesnego i duchowego, gdyż Chryzostom wzbraniał się przed odrzuceniem postrzegania cielesnego. Mógł na przykład twierdzić, że widzowie posługują się zwyczajnym sposobem patrzenia, podczas gdy uczestnicy wtajemniczenia cieszą się innym, wyższym zmysłem, a jednak unikał tej strategii, nie przyznając wyłączności duchowemu widzeniu, ani nie wyrzekając się postrzegania cielesnego. Każdy człowiek, niezależnie od tego czy jest ochrzczony czy też nie jest chrześcijaninem, widzi przy pomocy wzroku fizycznego. Jednak wnikliwy chrześcijanin posługuje się dwoma zestawami zmysłu wzroku: fizycznym i duchowym.

Warto zapytać, czy oba rodzaje widzenia, choć równocześnie funkcjonują u człowieka, są ze sobą kompatybilne? Rzeczywiście, czasami zdarzało się Chryzostomowi przedstawiać oba typy widzenia jako sprzeczne, jak można to zauważyć w poniższej - wyżej przytaczanej już - wypowiedzi:

„Wiary bowiem potrzeba w rzeczach, które się tu dzieją, i oczu duszy, by nie tylko o tym myśleć, co się widzi, ale by i to sobie uprzytomnić, czego się nie widzi. A tę właściwość mają oczy duszy: jak oczy ciała widzą to, co podpada pod zmysły, bo te nie widzą rzeczy widzialnych, lecz niewidzialne, jak gdyby one leżały ponad nami!"’36

Stwierdzenie, że oczy duszy „nie widzą rzeczy widzialnych” mogłoby sugerować, że postrzeganie duchowe stoi w opozycji do wzroku fizycznego. Ta niezgodność przypomina stanowisko Orygenesa ${ }^{37}$, który uznawał, że nie może współistnieć postrzeganie fizyczne i duchowe ${ }^{38}$. Jednak w wypowiedziach Jana Chryzostoma oba sposoby postrzegania działają równocześnie, a ich zgodność zasadza się w stosowaniu przez niego sformułowania ,jak gdyby”. Inaczej niż w przypadku Orygenesa, którego wizja duchowych zmysłów wyrastała z egzegezy biblijnej i problemów egzegetycznych, owo ,jak gdyby” sytuuje teorię Chryzostoma wśród zagadnień bardziej empirycznych ${ }^{39}$.

${ }^{36}$ Tenże, Catecheses ad illuminados 2, 9, SCh 50bis, 138, tłum. Kania, I, s. 44.

${ }^{37}$ Przykładowo, dla Orygenesa prawdziwa kontemplacja wymagała zamknięcia oczu cielesnych w celu widzenia oczami duszy. Por. tenże, Contra Celsum VII 39, ed. M. Borret, SCh 150, Paris 1969, 104, tłum. S. Kalinkowski: Orygenes, Przeciw Celsusowi, Warszawa 1986, 364: „Każdy prawdziwy chrześcijanin ma otwarte oczy duszy, a zamknięte oczy ciała, bo tylko w takim wypadku człowiek może oglądać najwyższego Boga i Jego Syna, który jest Słowem i Mądrością"; tamże VII 33, SCh 150, 88, thum. Kalinkowski, s. 360: „Dla poznania Boga ciało nie jest nam potrzebne”. Zob, Szczur, Rola ,zmystów wiary”, s. 299-301.

${ }^{38}$ Por. J.M. Dillon, Aisthêsis Noête: A Doctrine of Spiritual Senses in Origen and in Plotinus, w: Hellenica et Judaica. Hommage à Valentin Nikiprowetzky, ed. A. Caquot - M. Hadas-Lebel J. Riaud, Leuven 1986, 443-455, spec. 445-448.

${ }^{39}$ Por. C. Bell, Ritual: Perspectives and Dimensions, New York 1997, 160; taż, Performance, w: Critical Terms for Religious Studies, ed. M.C. Taylor, Chicago 1998, 205-224, spec. 208-209. Zob. T.F. Driver, The Magic of Ritual, San Francisco 1991, 88-89; S. Ashbrook Harvey, Embodiment in Time and Eternity: A Syriac Perspective, VTQ 43 (1999) 105-130; P. Cox Miller, Desert Asceticism and ,The Body from Nowhere”, JECS 2 (1994) 137-153. 
Chryzostomowe opisy przeciwstawnych i sprzecznych typów postrzegania, odczytywane w kontekście opisywanych obrzędów liturgicznych, nabierają odmiennego znaczenia. Widoczne to jest w przywoływanej już katechezie zawierającej opis obrzędów chrzcielnych i ich kulminację - pierwszą komunię świętą. W nauce tej Chryzostom napomina słuchaczy, aby

„rozważali o rzeczach niebieskich i przenieśli się myślą z ziemi do nieba, od rzeczy widzialnych do niewidzialnych. Wyraźniej bowiem niż cielesnym

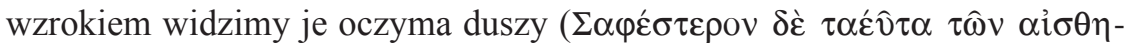

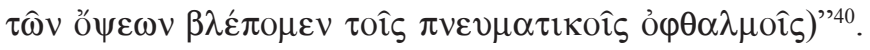

Zamiast nakreślać zakres niezgodności postrzegania fizycznego i duchowego, Chryzostom ukazuje ich ciągłość i podkreśla, że oczy duszy nie tylko nie ignorują i lekceważą wzroku fizycznego, lecz go przekształcają i wzbogacają. Celem zatem było nie odrzucenie odczuć fizycznych, ale nauczenie się, jak poprzez nie widzieć wyraźniej i dokładniej.

Dla zilustrowania tego „bogatszego” sposobu widzenia Chryzostom odwoływał się do pewnych wzorców. W jednej z katechez chwalił słuchaczy, którzy przyjechali z okolicznych wiosek, za „oderwanie się od rzeczy widzialnych, a wybrnie niewidzialnych, będących przedmiotem jedynie nadziei" ${ }^{41}$. Tutaj patrzenie duchowe zyskiwało swoją moc poprzez skłonienie człowieka wierzącego do dokonania właściwego wyboru: dzięki duchowemu postrzeganiu potrafił on zrezygnować z tego co widziały jego oczy fizyczne jednocześnie wybierając to, co widział oczami wiary.

Męczennicy - jak twierdził Chryzostom - byli w stanie rewizualizować swoją własną śmierć, i chociaż cielesnymi oczami widzieli oprawców zapalających stosy, na których mieli ponieść śmierć, to jednak oczami wiary widzieli Chrystusa oraz zastępy aniołów:

„Abyś wiedział, jak [męczennicy] wzgardzili wszystkimi rzeczami doczesnymi dla otrzymania dóbr wiecznych, rozważ: oczyma ciała widzieli jak tyran ziejący ogniem, ostrzący zęby, groźniejszy od lwa, zapalił stos, podłożył ogień, nie pomijając niczego, czym by mógł ich złamać i odebrać odwagę; oni tymczasem, porzuciwszy wszystkie rzeczy ziemskie, spoglądali oczyma wiary na Króla niebieskiego i na stojące przed Nim zastępy aniołów. Oto niewypowiedziane dobra w górze, o których myśleli. Całą myśl tam przeniósłszy nie zwracali uwagi na rzeczy doczesne, widzieli szarpiące ich ciała ręce katów, obejmujący ich ogień, płonące węgle. [...] Nie lękając się niczego z rzeczy widzialnych, odrzucili je wszystkie, jako sen i cień, kierując swój wzrok ku temu, czego bardzo pragnęli - ku rzeczom przyszłym”42.

\footnotetext{
${ }^{40}$ Joannes Chrysostomus, Catecheses ad illuminandos 2, 28, SCh 50bis, 149, thum. Kania, I, s. 50.

${ }^{41}$ Tamże 8, 6, SCh 50bis, 251, thum. Kania, I, s. 111.

${ }^{42}$ Tamże 7, 18-19, SCh 50bis, 237-238, thum. Kania, I, s. 102-103.
} 
Zatem zadaniem oczu wiary, poza dokonywaniem wyboru obrazów, było też tworzenie obrazów i wyobrażeń dla potęgowania lub - w niektórych przypadkach - odrzucenia tego, co widziały oczy ciała.

Dla oczu wiary kluczowe znaczenie miała zdolność umysłu do tworzenia potrzebnych wyobrażeń. Dokładnie tak samo, jak męczennicy - kiedy oczami cielesnymi widzieli płonący ogień - oczami wiary widzieli Chrystusa i aniołów, tworząc w swych umysłach obraz nieba, tak neofici patrząc na obrzędy wtajemniczenia musieli tworzyć w swych umysłach obrazy innych rzeczywistości - duchowych. Dlatego też Chryzostom porównywał przygotowanie do chrztu ze szkicowaniem obrazu. Zachęcał słuchaczy katechez popadających w złe nawyki, aby wyobrazili sobie malarzy, którzy przygotowują obrazy:

„Weźmy sobie za wzór postępowanie malarzy! Gdy malarz postawi tablicę i pociągnie tu i tam białe linie, by naszkicować artystyczny obraz, może już $\mathrm{z}$ nieograniczoną swobodą to i tamto nakreślić i nowe namalować, może błędy poprawić i należycie przedstawić, ale tylko tak długo, jak długo nie nałożył farb, które obraz pierwszy uczyniły odbiciem prawdziwym i właściwym. Jeśli farby już naniósł, już nie może ich samowolnie wykreślić i nowych wymalować, bo przyniósłby szkodę pięknemu obrazowi i samego siebie wystawił na naganę"43.

Zanim artysta nałoży farby na przygotowany szkic, może swobodnie go zmieniać: wycierać, poprawiać, a nawet zastępować naszkicowany obraz innym. Gdy jednak na szkic nałoży farby, to wówczas bardzo trudno jest cokolwiek zmienić w tym obrazie, a przez wprowadzanie poprawek można go nawet zepsuć. Dlatego katechumeni powinni pracować nad sobą i usuwać złe nawyki przed przyjęciem chrztu. Mając to na uwadze Antiocheńczyk zachęcał:

„Patrz na swą duszę jak na obraz: zanim ten obraz przez działanie Ducha Świętego otrzyma prawdziwy blask farb, usuwaj złe nawyki [...]; usuń nawyk, abyś po chrzcie do niego nie wracał. Grzechy gładzi chrzest, nawyk popraw ty sam, abyś - gdy obraz otrzyma barwy i lśni w swym pięknie - nie miał już nic do zmazania i danego ci przez Boga piękna przez rany i blizny nie zeszpecił" ${ }^{\prime 4}$.

\section{$* * *$}

W podsumowaniu należy zauważyć, że Jan Chryzostom wyposażał neofitę w oczy wiary, które zdolne były skłonić umysł do stworzenia duchowych wyobrażeń przestrzeni i obrazów, które miały wspomagać odczucia fizyczne katechumena/neofity we właściwym zrozumieniu obrzędów wtajemniczenia

\footnotetext{
${ }^{43}$ Tenże, Catecheses ad illuminandos, catechesis 2, 8, PG 49, 235, thum. Kania, II, s. 57.

${ }^{44}$ Tamże, PG 49, 235, thum. Kania, II, s. 57-58.
} 
chrześcijańskiego. Pomimo że, Chryzostom zastanawiał się też nad zmysłową dezorientacją, jakiej mógł doświadczyć wierny, to jednak polegał on na wyobrażeniach, które miały umożliwić wiernemu np. widzieć chleb jako Ciało Chrystusa. Przypominał też neofitom o ich nowej godności, wspaniałości, blasku i świetności, symbolizowanych przez białe szaty.

\author{
THE ROLE OF THE SPIRITUAL PERCEPTION \\ IN THE CATECHETICAL TEACHING OF JOHN CHRYSOSTOM
}

\title{
(Summary)
}

Among the works of John Chrysostom is twelve baptismal catecheses which he delivered most probably in Antioch. In these catecheses he tried to explain ceremonies connected with initiation. To realize his goal he appealed repeatedly to the sense of sight and he reminded catechumens/neophytes that everything they see has spiritual significance. This spiritual reality can be recognized by the organ, which he called "the eyes of the soul" (oi $\tau \hat{\eta} \varsigma \psi v \chi \hat{\eta} \varsigma$ ỏ $\varphi \theta \alpha \lambda \mu$ oí; oi ỏ $\varphi \theta \alpha \lambda \mu$ oi

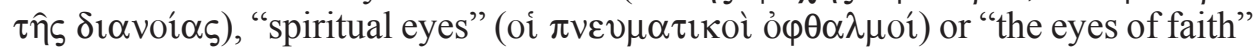

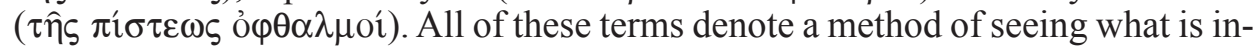
visible to the eyes of the body. In this way John Chrysostom equipped a neophyte with the eyes of faith able to induce the mind to create spiritual images of space. These images were meant to lead the physical feelings of catechumen/neophyte in the proper understanding of the rites of Christian initiation.

Key words: John Chrysostom, mystagogy, spiritual senses.

Słowa kluczowe: Jan Chryzostom, mistagogia, duchowe zmysły. 